\title{
Effects of Multidrug Resistance Gene Expression in Acute Erythroleukemia
}

Fermina M. Mazzella, M.D., Areta Kowal-Vern, M.D., M. Atef Shrit, M.D., James T. Rector, M.D., James D. Cotelingam, M.D., Harold R. Schumacher, M.D.

Department of Pathology and Laboratory Medicine, University of Cincinnati Medical Center (FMM, HRS), Cincinnati, Ohio; Department of Pathology and Laboratory Medicine, Loyola University Medical Center (AK-V), Maywood, Illinois; Department of Pathology, Miami Valley Hospital (MAS), Dayton, Ohio; and National Naval Medical Center, Department of the Navy (JTR, JDC), Bethesda, Maryland

Acute erythroleukemia is a relatively rare disorder of a multilineal nature. Patients with this type of leukemia traditionally have been treated with a standard myeloid protocol, with a wide variation in prognosis between M6a, which has a similar prognosis to acute myelogenous leukemias, and M6b, with an extremely poor outcome despite aggressive therapy.

Forty-eight archival cases of acute erythroleukemia, subtypes M6a (the traditional FAB-M6), M6b (pure erythroleukemia), and M6c ( $>30 \%$ myeloblasts and $>30 \%$ pronormoblasts by FAB exclusion criteria), were evaluated for multidrug resistance gene (MDR-1) status. Findings were correlated with clinical course and karyotypes.

Immunohistochemical stain for the protein product of MDR-1, P-glycoprotein, was variably positive in 11 of 23 patients with M6a, as well as in all of the patients with M6b (strongly positive) and M6c (weakly positive). P-glycoprotein expression positively correlated with unfavorable cytogenetic aberrations, poor response to chemotherapeutic agents, and short survival. Most significant was that P-glycoprotein expression demonstrated a negative additive effect on response to treatment and prognosis with unfavorable cytogenetic anomalies.

P-glycoprotein expression and multiple cytogenetic anomalies most probably contribute to the resistance to chemotherapy and poor survival characteristic of the patients with M6b (mean survival, $3.15 \pm 4.2 \mathrm{mo}$ ) and M6c (mean survival, $10.5 \pm 12.7$ mo). Because patients with M6b and M6c have increased numbers of pronormoblasts in their bone marrow and past chemotherapeutic attempts have

Copyright () 2000 by The United States and Canadian Academy of Pathology, Inc.

VOL. 13, NO. 4, P. 407, 2000 Printed in the U.S.A.

Date of acceptance: September 13, 1999.

Address reprint requests to: Fermina M. Mazzella, M.D., Department of Pathology and Laboratory Medicine, The Guthrie Clinic, Guthrie Square,

Sayre, PA 18840; e-mail: fmazzella@clinic.guthrie.org; fax: 570-882-4193. failed, chemotherapy directed at these cells is appropriate. Additional therapy directed toward the $M D R-1$ gene and its protein product seems indicated from our findings.

KEY WORDS: Acute erythroleukemia, Multidrug resistance gene (MDR-1), P-glycoprotein.

Mod Pathol 2000;13(4):407-413

The hallmark of the multidrug resistance phenotype is cross-resistance to multiple compounds that are unrelated in structure, cellular target, and mode of action (1). Overexpression of the protein product of the multidrug resistance gene (MDR-1), P-glycoprotein, is a major, as well as the best understood, mechanism of multidrug resistance. It is a large, integral membrane protein that seems to function as an adenosine triphosphate-dependent, selective drug efflux pump (2) and confers resistance to a variety of drugs from different mechanistic and structural classes (3).

As patients with acute erythroleukemia, particularly the M6b and M6c subtypes, characteristically demonstrate an unusually poor response to chemotherapeutic agents (4-6), overexpression of the $M D R-1$ product was postulated to play an important role. We therefore performed immunohistochemical studies for P-glycoprotein on 48 archival cases of acute erythroleukemia and correlated these findings with clinical presentation, cytogenetic analyses, chemotherapeutic regimens, follow-up, and survival.

\section{MATERIALS AND METHODS}

\section{Case Material Procurement}

Forty-eight archival cases of acute erythroleukemia, diagnosed between 1984 and 1997, were available for review and performance of additional immunohistochemical stains; 14 from the files of the 


\begin{tabular}{|c|c|c|c|c|c|}
\hline Case & $\begin{array}{l}\text { Age }(\mathrm{y}) / \\
\text { Gender }\end{array}$ & $\begin{array}{l}\text { Significant History/ } \\
\text { Toxin Exposure }\end{array}$ & Cytogenetics & Treatment/Remission & $\begin{array}{l}\text { Survival } \\
\text { (mo) }\end{array}$ \\
\hline \multicolumn{6}{|l|}{ M6a } \\
\hline 1 & $58 / \mathrm{M}$ & MDS/EtOH abuse & $\begin{array}{l}\text { 45XY,dir ins }(1 ; 5)(1 \text { pter }>1 \text { p36::5q35>5q31:: } \\
\quad \text { lp36>1qter;5pter }>5 \text { q31::5q36>5qter), }-20\end{array}$ & Symptom relief only & 0.5 \\
\hline 2 & $59 / \mathrm{M}$ & MDS & Unavailable & Unknown & 8.5 \\
\hline 4 & $59 / \mathrm{M}$ & Chronic anemia & Unavailable & Unknown & 13.5 \\
\hline 5 & $38 / \mathrm{M}$ & MDS & 46XY-limited sample & Ara-C, daunorubicin/Remission & 35 \\
\hline 6 & $56 / \mathrm{M}$ & MDS & $46 \mathrm{XY}$ & Ara-C, daunorubicin/Remission & 28.5 \\
\hline 18 & $67 / \mathrm{M}$ & Sideroblastic anemia & $46 \mathrm{XY}$ & Ara-C, daunorubicin/Remission & 22 \\
\hline 19 & $25 / \mathrm{M}$ & EtOH abuse & $46 X Y, t(3 ; 5)(q 21 ; q 31)$ & $\begin{array}{l}\text { Multiple courses: ara-C, } \\
\text { daunorubicin/Multiple } \\
\text { remissions }\end{array}$ & 96 \\
\hline 22 & $38 / \mathrm{F}$ & Pesticides & Not performed & Ara-C, daunorubicin/Remission & 37 \\
\hline 23 & $81 / \mathrm{M}$ & EtOH abuse & $46 X Y$ & Symptom relief only & 18.5 \\
\hline 24 & $37 / \mathrm{M}$ & None & Not performed & Ara-C, daunorubicin/Remission & 32 \\
\hline 25 & $60 / \mathrm{M}$ & EtOH abuse & $47 \mathrm{XY},+8$ & Ara-C, daunorubicin/Remission & $\begin{array}{l}\text { Alive } 120 \\
\text { mo later }\end{array}$ \\
\hline 26 & $73 / \mathrm{F}$ & $\begin{array}{l}\text { Pesticides/Marrow injury } \\
\text { syndrome }\end{array}$ & $45 X X,-7$ & Erythropoietin/No remission & 14 \\
\hline 28 & $75 / \mathrm{F}$ & None & $\begin{array}{l}\text { 46XX,del(5) (q11;q35),t(6;10)(p21.3;p15),-7,+8,der } \\
\quad(12) \mathrm{t}(7 ; 12)(\mathrm{p} 13 ; \mathrm{p} 13), \mathrm{t}(16 ; 20)(\mathrm{q} 13 ; \mathrm{q} 13)\end{array}$ & Symptom relief only & $\begin{array}{l}\text { Alive } 66 \mathrm{mo} \\
\quad \text { later }\end{array}$ \\
\hline 31 & $57 / \mathrm{M}$ & None & $46 X Y, \operatorname{inv}(3)(q 21 ; q 26)$ & Ara-C, daunorubicin/Remission & 19 \\
\hline 32 & $71 / \mathrm{M}$ & None & $46 \mathrm{XY}$ & Symptom relief only & $\begin{array}{l}\text { Lost to } \\
\text { follow-up }\end{array}$ \\
\hline 33 & $45 / \mathrm{M}$ & $\begin{array}{l}\text { Multiple } \\
\text { myeloma/Melphalan }\end{array}$ & $\begin{array}{l}45 \mathrm{XY},-5,-6,-11,-13,-18, \mathrm{t}(9 ; ?)(\mathrm{p} 22 ; ?) \\
\quad \operatorname{del}(16)(\mathrm{q} 22 ; \mathrm{q} 24),+\operatorname{der}(5) \mathrm{t}(5 ; 13)(\mathrm{q} 11 ; \mathrm{q} 4), \operatorname{der}\left(11^{*}\right) \mathrm{t} \\
(11 ; 11)(\mathrm{p} 15 ; \mathrm{q} 21),+\operatorname{der}(18) \mathrm{t}(6 ; 18)(\mathrm{q} 16 ; \mathrm{q} 23),+\mathrm{I}\left(11 \mathrm{p}^{*}\right)\end{array}$ & Ara-C, daunorubicin/Remission & 24 \\
\hline 34 & $35 / \mathrm{M}$ & $\begin{array}{l}\text { Hodgkin's disease, MDS/ } \\
\text { Cytoxan, radiation } \\
\text { therapy }\end{array}$ & Not performed & $\begin{array}{l}\text { Busulphan, BM } \\
\text { transplant/Remission }\end{array}$ & 4 \\
\hline 35 & $66 / \mathrm{M}$ & MDS/EtOH abuse & $46 X Y$ & Ara-C, daunorubicin/Remission & 24 \\
\hline 37 & $69 / \mathrm{M}$ & MDS/EtOH abuse & $46 X Y$ & Ara-C, daunorubicin/Unknown & 3 \\
\hline 38 & $45 / \mathrm{F}$ & MDS & $46 X X$ & Symptom relief only & $\begin{array}{l}\text { Lost to } \\
\text { follow-up }\end{array}$ \\
\hline 41 & $69 / \mathrm{M}$ & None & Not performed & Ara-C, daunorubicin/Remission & $\begin{array}{l}\text { Lost to } \\
\text { follow-up }\end{array}$ \\
\hline 42 & $81 / \mathrm{F}$ & Unavailable & Unavailable & Unknown & $\begin{array}{l}\text { Lost to } \\
\text { follow-up }\end{array}$ \\
\hline 46 & $34 / \mathrm{M}$ & None & $\begin{array}{l}47 \mathrm{XY},-5,-7,-16,-17,-18,-19, \operatorname{del}(6)(\mathrm{q} 21), \text { dict } \\
\quad(12 ; 13)(\mathrm{p} 13 ; \mathrm{p} 11),+\operatorname{der}(7) \mathrm{t}(7 ; ?)(\mathrm{q} 22 ; ?),+\operatorname{der}(16) \\
\mathrm{t}(16 ; ?)(\mathrm{q} 22 ; ?),+\operatorname{der}(17) \mathrm{t}(17 ; ?)(\mathrm{p} 11.2 ; ?),+\operatorname{der}(19) \\
\mathrm{t}(19 ; ?)(\mathrm{q} 13 ; ?),+\operatorname{mar} 1,+\mathrm{mar} 2,+\operatorname{mar} 3,+ \text { mar4 }\end{array}$ & Unknown & $\begin{array}{l}\text { Lost to } \\
\text { follow-up }\end{array}$ \\
\hline \multicolumn{6}{|c|}{ - } \\
\hline 9 & $52 / \mathrm{M}$ & $\begin{array}{l}\text { Renal transplant/EtOH } \\
\text { abuse, cyclosporine }\end{array}$ & $\begin{array}{l}42-44 X Y,-5, \operatorname{del}(7)(\mathrm{q} 11),-8, \operatorname{del}(11)(\mathrm{p} 11),-18,-19 \\
\quad-19,-20,+4 \mathrm{mar}\end{array}$ & Ara-C, daunorubicin/Remission & 4 \\
\hline 11 & $71 / \mathrm{F}$ & $\begin{array}{l}\text { Tuberculosis, } \\
\text { ?MDS/Isoniazid }\end{array}$ & $45 X X, \operatorname{del}(1)(p 22), \operatorname{del}(5)(q 13 ; q 33),-9,-17,+$ mar & Ara-C/No remission & 0.5 \\
\hline 12 & $57 / \mathrm{F}$ & Haldol & Not performed & Symptom relief only & 0.5 \\
\hline 14 & $73 / \mathrm{F}$ & $\begin{array}{l}\text { Breast cancer/Alkylating } \\
\text { chemotherapy, } \\
\text { radiation therapy }\end{array}$ & $\begin{array}{l}43 \mathrm{XX},-5,-7,+8,-16,-17, \mathrm{t}(12 ; ?)(\mathrm{p} 13 ; ?), \mathrm{t}(14 ; ?) \\
\quad(\mathrm{p} 11 ; ?), \operatorname{dic}(3 ; 22)(\mathrm{p} 21 ; \mathrm{p} 11),+\operatorname{der}(5) \mathrm{t}(5 ; 17)(\mathrm{q} 13 ; \mathrm{p} 11)\end{array}$ & $\begin{array}{l}\text { Ara-C, daunorubicin/No } \\
\text { remission }\end{array}$ & 3.5 \\
\hline 15 & $39 / \mathrm{M}$ & None & $\begin{array}{l}\text { 44XY,der(5)t(5;12)(q11;p11),del(7)(q21;q35), } \\
\quad \operatorname{der}(7) \mathrm{t}(7 ; 12)(7 \mathrm{qter}->7 \mathrm{p} 15:: 12 \mathrm{q} 13->12 \mathrm{q} 2 ? 2:: \\
\text { 12q2?4->12qter),der(11)t(11;14)(p15;p11),-12, } \\
-14\end{array}$ & Ara-C, daunorubicin/Remission & 14.5 \\
\hline 16 & $63 / \mathrm{M}$ & None & $44 \mathrm{X},-\mathrm{Y},-17, \operatorname{del}(5)(\mathrm{q} 13 ; \mathrm{q} 34), \mathrm{t}(17 ; ?)(\mathrm{q} 25 ; ?),+\operatorname{mar} 3$ & $\begin{array}{l}\text { Ara-C, daunorubicin/No } \\
\text { remission }\end{array}$ & 1.5 \\
\hline 21 & $77 / \mathrm{M}$ & None & Not performed & Ara-C, daunorubicin/Unknown & $\begin{array}{l}\text { Lost to } \\
\text { follow-up }\end{array}$ \\
\hline 27 & $67 / \mathrm{M}$ & $\begin{array}{l}\text { Adenocarcinoma of lung, } \\
\text { prostate; ?sideroblastic } \\
\text { anemia/"Chemotherapy" }\end{array}$ & $46 X Y$ & Ara-C, daunorubicin/Unknown & $\begin{array}{l}\text { Lost to } \\
\text { follow-up }\end{array}$ \\
\hline 30 & $47 / \mathrm{M}$ & $\begin{array}{l}\text { Renal transplant, MDS/ } \\
\text { Cyclosporine }\end{array}$ & $\begin{array}{l}40-42 \mathrm{X},-\mathrm{Y},-5, \operatorname{del}(5)(\mathrm{q} 13 ; \mathrm{q} 33),-7, \operatorname{der}(9) \mathrm{t}(9 ; 13) \\
\quad(\mathrm{p} ? 11 ; \mathrm{q} ? 12),-10,-13,-16,-17,-20,-21, \text { add } \\
\text { (22)(p11), +1-4mar/67-84<4n>,XXX,-Y,-5, } \\
\quad-5,-7,-9,-9, \operatorname{der}(9) \mathrm{t}(9 ; 13)(\mathrm{p} ? 11 ; \mathrm{q} ? 12) \mathrm{x} 2,-10, \\
-10,-13,-13,-14,-15,-16,-17,-20, \operatorname{add}(22) \\
\text { (p11),+2-14mar }\end{array}$ & $\begin{array}{l}\text { Multiple courses: ara-C, } \\
\text { daunorubicin/No remission }\end{array}$ & 2.5 \\
\hline 36 & $72 / \mathrm{M}$ & MDS & Not performed & $\begin{array}{l}\text { Ara-C, daunorubicin/No } \\
\text { remission }\end{array}$ & 1 \\
\hline 39 & $32 / \mathrm{M}$ & $\begin{array}{l}\text { Bloom's syndrome/EtOH } \\
\text { abuse }\end{array}$ & $\begin{array}{l}\text { 44X,-Y,-7,del(4)(q22;q31),del(5) (q12;q35), del(12) } \\
\quad(\mathrm{p} 12.1 ; \mathrm{p} 13.1),-20,+\operatorname{mar}\end{array}$ & Doxorubicin/No remission & 1.5 \\
\hline
\end{tabular}




\begin{tabular}{|c|c|c|c|c|c|}
\hline Case & $\begin{array}{l}\text { Age }(y) / \\
\text { Gender }\end{array}$ & $\begin{array}{l}\text { Significant History/ } \\
\text { Toxin Exposure }\end{array}$ & Cytogenetics & Treatment/Remission & $\begin{array}{l}\text { Survival } \\
\text { (mo) }\end{array}$ \\
\hline 40 & $82 / \mathrm{M}$ & None & Not performed & $\begin{array}{l}\text { Ara-C, daunorubicin/No } \\
\text { remission }\end{array}$ & 2 \\
\hline 43 & $61 / \mathrm{F}$ & $\begin{array}{l}\text { Small cell carcinoma of } \\
\text { lung/Etoposide }\end{array}$ & $\begin{array}{l}\text { 44-47XX, }-\mathrm{X}, \operatorname{del}(4)(\mathrm{q} 12),-5,+6, \operatorname{del}(7)(\mathrm{q} 22),+8,-12, \\
\quad-13,-15, \operatorname{der}(17),-17,-18, \operatorname{add}(19)(\mathrm{p} 13.3), \operatorname{der}(21) \\
\quad+\operatorname{mar} 1,+\operatorname{mar} 2,+\operatorname{mar} 3,+\operatorname{mar} 4,+\operatorname{mar} 5,+\mathrm{R}\end{array}$ & Unknown & $\begin{array}{l}\text { Lost to } \\
\text { follow-up }\end{array}$ \\
\hline 44 & $23 / \mathrm{F}$ & Sideroblastic anemia & $\begin{array}{l}59 X X,+1,+\operatorname{der}(1), \operatorname{der}(4), \operatorname{der}(5),+\operatorname{der}(6),+8,+\operatorname{der}(11), \\
\quad+12,-13,+14,+15,+15, \operatorname{der}(17),+19,+20,+21,+21, \\
\quad+\operatorname{mar} / 59 X X,+\operatorname{der}(1),+2, \operatorname{der}(4), \operatorname{der}(5),+\operatorname{der}(6), \\
\quad+\operatorname{der}(8),+\operatorname{der}(11),+15,+19,+20,+21,+21,+22,+\operatorname{mar}\end{array}$ & BM transplant & $\begin{array}{l}\text { Lost to } \\
\text { follow-up }\end{array}$ \\
\hline 45 & $67 / \mathrm{M}$ & None & $\begin{array}{l}41-43 X Y,-2,-5,-7,-8,-15,-16,-17,-19,-22 \\
\quad+\operatorname{der}(2) \mathrm{t}(2 ; ?)(\mathrm{p} 21 ; ?),+\operatorname{der}(5) \mathrm{t}(5 ; ?)(\mathrm{q} 11 ; ?),+\operatorname{der}(17) \\
\quad \mathrm{t}(17 ; ?)(\mathrm{q} 23 ; ?),+\operatorname{der}(19) \mathrm{t}(19 ; ?)(\mathrm{q} 13.2),+\operatorname{der}(22) \\
\quad \mathrm{t}(22 ; ?)(\mathrm{p} 11 ; ?),+\operatorname{mar}\end{array}$ & "Chemotherapy"/No remission & $\begin{array}{l}\text { Lost to } \\
\text { follow-up }\end{array}$ \\
\hline \multicolumn{6}{|c|}{ (2) } \\
\hline 3 & $86 / \mathrm{M}$ & Unavailable & Unavailable & Unknown & 11.5 \\
\hline 7 & $62 / \mathrm{F}$ & None & $\begin{array}{l}\text { 45XX, }-2, \operatorname{der}(5) \operatorname{del}(5)(\mathrm{q} 22 ; \mathrm{q} 31), \mathrm{t}(2 ; 5)(\mathrm{q} 21 ; \mathrm{q} 33),-7, \\
\quad \operatorname{der}(7) \mathrm{t}(2 ; 7)(\mathrm{p} 11 ; \mathrm{q} 36), \mathrm{t}(12 ; 12)(\mathrm{p} 13 ; \mathrm{q} 13), \operatorname{add}(17)(\mathrm{q} 25) \\
\quad \operatorname{del}(20)(\mathrm{q} 11 ; \mathrm{q} 13),+ \text { mar }\end{array}$ & Symptom relief only & 2 \\
\hline 8 & $52 / \mathrm{M}$ & EtOH abuse, diesel fuel & $46 \mathrm{XY}$ & Ara-C, daunorubicin/Remission & 12.5 \\
\hline 10 & $85 / F$ & $\begin{array}{l}\text { Breast cancer, chronic } \\
\text { anemia/Alkylating } \\
\text { chemotherapy, } \\
\text { radiation therapy }\end{array}$ & $53 X X,+1,+2, \operatorname{del}(5)(q 15 ; q 33),+9,+11,+16,+19,+21$ & Symptom relief only & 7 \\
\hline 13 & $62 / \mathrm{F}$ & Unavailable & Unavailable & Unknown & 0.75 \\
\hline 17 & $86 / \mathrm{F}$ & MDS & Unavailable & Unknown & $\begin{array}{l}\text { Lost to } \\
\text { follow-up }\end{array}$ \\
\hline 20 & $69 / \mathrm{F}$ & Unavailable & Unavailable & Unknown & 7 \\
\hline 29 & $14 / \mathrm{F}$ & None & $46 X X$, dir dup(13) (q14>q32) & $\begin{array}{l}\text { Ara-C, etoposide, } \\
\text { dexamethasone, intrathecal } \\
\text { ara-C, } 6 \mathrm{TG} \text {, total body } \\
\text { irradiation, BM transplant/ } \\
\text { Remission }\end{array}$ & 40 \\
\hline 47 & $73 / \mathrm{F}$ & $\begin{array}{l}\text { Large cell lymphoma/ } \\
\text { Alkylating } \\
\text { chemotherapy }\end{array}$ & Not performed & Unknown & $\begin{array}{l}\text { Lost to } \\
\text { follow-up }\end{array}$ \\
\hline 48 & $65 / \mathrm{F}$ & None & Not performed & Ara-C, daunorubicin/Remission & 3 \\
\hline
\end{tabular}

MDS, myelodysplastic syndrome; BM, bone marrow.

University of Cincinnati Medical Center, 22 from Loyola University Medical Center, 7 from Miami Valley Hospital, 4 from the National Naval Medical Center, and 1 from Scottish Rite Children's Hospital in Atlanta.

\section{Case Classification}

The cases were divided into three groups, based on a 500-cell count performed on the bone marrow aspirate smears, as previously described (6). All cases had normal serum vitamin $B_{12}$ and folate levels and characteristically displayed more than $50 \%$ erythroid component. The cases were subdivided into groups: M6a (23 cases corresponding to the traditional FAB-M6 category, demonstrating at least $30 \%$ myeloblasts of the nonerythrocytic component), M6b (15 cases of pure erythroleukemia, with $>30 \%$ pronormoblasts of the erythrocytic series), and M6c (10 cases with $>30 \%$ myeloblasts of the nonerythrocytic elements and $>30 \%$ pronormoblasts of the erythrocytic component). Morphologic interpretation was confirmed with immunohistochemical stains for myeloperoxidase and hemoglobin, and archival flow cytometric analyses when available.

\section{Case Analysis}

Review of pertinent clinical information, including medical history, toxin exposure $(7,8)$, alcohol use, cytogenetic analyses, prior and subsequent use of chemotherapy, and survival from the time of diagnosis of acute leukemia, was performed for all cases through chart review and contact with the Tumor Registry of each participating institution, as previously described (6).

Cytogenetic analyses were divided into favorable [t(8;21); inv 16; t(16;16); +14], unfavorable [-5/ 5q-; $-7 / 7 \mathrm{q}-$; inv 3 ; 11q abnormalities; $17 \mathrm{p}$ abnormalities or i(17q); del 20q; +13; t(9;22); dmins; multiple cytogenetic aberrations ( $>2$ abnormalities)], and intermediate [normal karyotype and all other abnormalities], as previously described (9).

\section{Immunohistochemistry}

Immunohistochemical stain for P-glycoprotein (NCL-pGLYp, Ventana 1:75, Novacastra, Newcastle 
upon Tyne, UK) was performed according to the method of Hsu et al. (10), after antigen retrieval as per Kawai et al. (11). All slides were reviewed for quality, and positivity (strong versus weak) or negativity of the leukemic populations was determined. In keeping with the literature, cases with at least $10 \%$ of cells reacting with the immunostain were deemed "positive." The intensity of the stain was concluded to be either "strong" or "weak."

\section{Statistics}

The blinded results were tabulated according to subtype, and univariant statistical analyses were performed (confidence intervals, $\chi^{2}$ analysis, Komolgorov-Smirnov analysis, linear regression) using the StatMost statistical program (DataMost Corp., Salt Lake City, UT). Multivariant analysis was not performed because of the small numbers of cases in each group.

\section{RESULTS}

\section{Clinical Data}

Demographic data, significant medical history, cytogenetic analyses, and clinical presentation of these patients have been reported (6). The pertinent clinical findings for each patient are summarized in Table 1. Significant is that acute erythroleukemia has been shown to evolve frequently from a prior myelodysplastic syndrome, suggesting that it is frequently a therapy-induced or myelodysplastic syndrome-derived acute leukemia $(6,12)$. In addition, approximately half of all patients with acute erythroleukemia of all subtypes have a history of toxin and/or alcohol exposure (6). Analysis of these poor prognostic indicators and their relationship to the various subtypes has been reported (6, 12).

A favorable karyotype was not present in any of the patients in the present study. An intermediate karyotype was present in 10 of $16 \mathrm{M} 6 \mathrm{a}$ cases (62.5\%), 1 of 11 M6b cases (9\%), and 2 of 4 M6c cases $(50 \%)$. An unfavorable karyotype was identified in 6 of 16 M6a cases (37.5\%), 10 of 11 M6b cases (91\%), and 2 of $4 \mathrm{M} 6 \mathrm{c}$ cases (50\%).

Thirty-eight patient records contained treatment histories. Of these, 23 patients $(60.5 \%)$ had received the standard myeloid protocol of high dose ara- $\mathrm{C}$ followed by daunorubicin (12 M6a, 9 M6b, 2 M6c). Other therapies included symptomatic relief only (5 M6a, 1 M6b, 2 M6c), bone marrow transplantation (1 M6a, 1 M6b, 1 M6c), high-dose ara-C only (1 M6b), erythropoietin (1 M6a), doxorubicin (1 M6b), and an unknown chemotherapeutic regimen (1 M6b). Remission in the M6a and M6c groups was achieved in all patients who received ara-C/dauno- rubicin or a bone marrow transplant (100\%). In the M6b group, remission was obtained in only two patients who were treated with ara-C/daunorubicin (Patients 9 and 15).

Overall survival for each subtype was as follows: M6a, $31.4 \pm 32$ mo (median survival, 24 mo); M6b, $3.15 \pm 4.2$ mo (median survival, $1.75 \mathrm{mo}$ ); M6c, $10.5 \pm 12.7$ mo (median survival, 7 mo). Patient prognosis in the M6a group, divided according to P-glycoprotein status (Table 2), revealed mean survival of $11.2 \pm 9.8$ mo for the strongly reactive stain (median survival, $8.5 \mathrm{mo}$ ), $17.4 \pm 10.2 \mathrm{mo}$ for the weakly reactive stain (median survival, $19 \mathrm{mo}$ ), and $47.5 \pm 38.7$ mo for the negative stain (median survival, $35 \mathrm{mo}$ ). Statistical analysis for survival was performed for strong versus negative stain $(P=.01)$, weak versus negative stain $(P=.026)$, and strong versus weak stain $(P=.2)$. The patients with M6b showed a mean survival of $1.6 \pm 1.03$ mo for the strongly reactive stain (median survival, $1.5 \mathrm{mo}$ ) and $9.3 \pm 7.4$ mo (median survival, $9.25 \mathrm{mo}$ ) for the weak immunostain $(P=.08)$. Mean survival for the patients with M6c was $4.5 \pm 3.5$ mo for the strong (median survival, $4.5 \mathrm{mo}$ ) and $12.5 \pm 14.2 \mathrm{mo}$ (median survival, $9.25 \mathrm{mo})$ for the weak stain $(P=.12)$.

\section{Bone Marrow Findings}

The histologic features and staining patterns for the bone marrow aspirates and biopsies of these cases have been reported $(6,12)$.

Immunohistochemical stain for P-glycoprotein revealed that 12 of 23 samples of patients with M6a were negative for protein expression $(52.3 \%$ ) (Fig. 1), whereas 6 patient samples stained weakly (26\%) and 5 demonstrated a strong positivity $(21.7 \%)$. The samples of patients with M6b all stained positive for P-glycoprotein (Fig. 2); 13 of 15 stained strongly (86.7\%) and 2 stained weakly (13.3\%) positive. Find-

\begin{tabular}{|c|c|c|c|}
\hline & M6a & M6b & M6c \\
\hline \multicolumn{4}{|l|}{ Overall survival (mo) } \\
\hline Mean survival & $31.4 \pm 32$ & $3.15 \pm 4.2$ & $10.5 \pm 12.7$ \\
\hline Median survival & 24 & 1.75 & 7 \\
\hline \multicolumn{4}{|c|}{ Survival for treated patients (mo) } \\
\hline Mean survival & $35.3 \pm 34.3$ & $3.4 \pm 4.3$ & $18.5 \pm 19.2$ \\
\hline Median survival & 28.5 & 2 & 12.5 \\
\hline \multicolumn{4}{|c|}{$\begin{array}{l}\text { Mean survival (mo) based on P- } \\
\text { glycoprotein expression }\end{array}$} \\
\hline Negative results & $47.5 \pm 38.7$ & N/A & N/A \\
\hline Weakly positive & $17.4 \pm 10.2$ & $9.3 \pm 7.4$ & $12.5 \pm 14.2$ \\
\hline Strongly positive & $11.2 \pm 9.8$ & $1.6 \pm 1.03$ & $4.5 \pm 3.5$ \\
\hline \multicolumn{4}{|c|}{$\begin{array}{l}\text { Median survival (mo) based on } \\
\text { P-glycoprotein expression }\end{array}$} \\
\hline Negative results & 35 & N/A & $\mathrm{N} / \mathrm{A}$ \\
\hline Weakly positive & 19 & 9.25 & 9.25 \\
\hline Strongly positive & 8.5 & 1.5 & 4.5 \\
\hline
\end{tabular}

N/A, not applicable. 


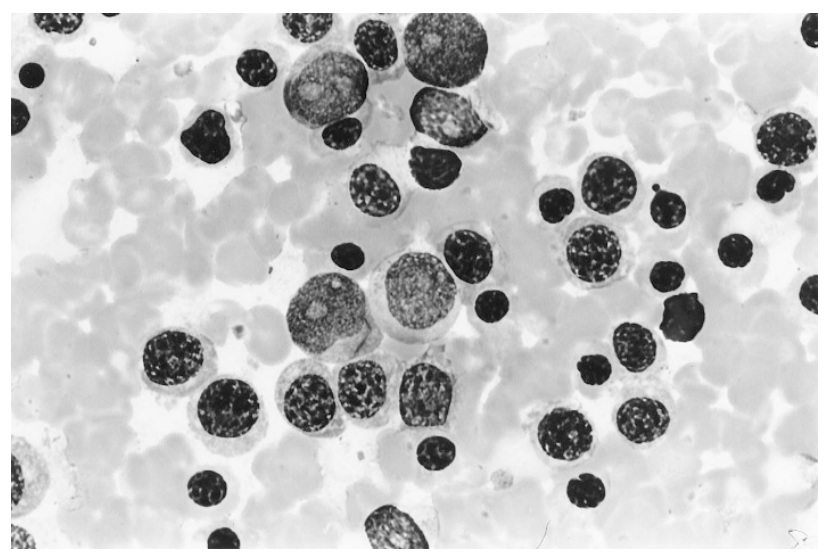

FIGURE 1. Representative photomicrograph of acute erythroleukemia, M6a (Wright-Giemsa stained aspirate smear, $1000 \times$ oil immersion).

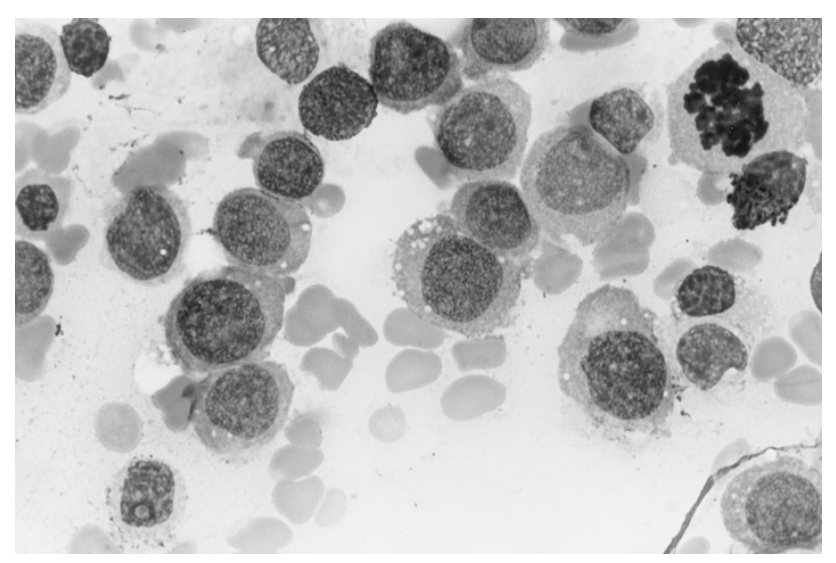

FIGURE 2. Representative photomicrograph of acute erythroleukemia, M6b (Wright-Giemsa stained aspirate smear, $1000 \times$ oil immersion).

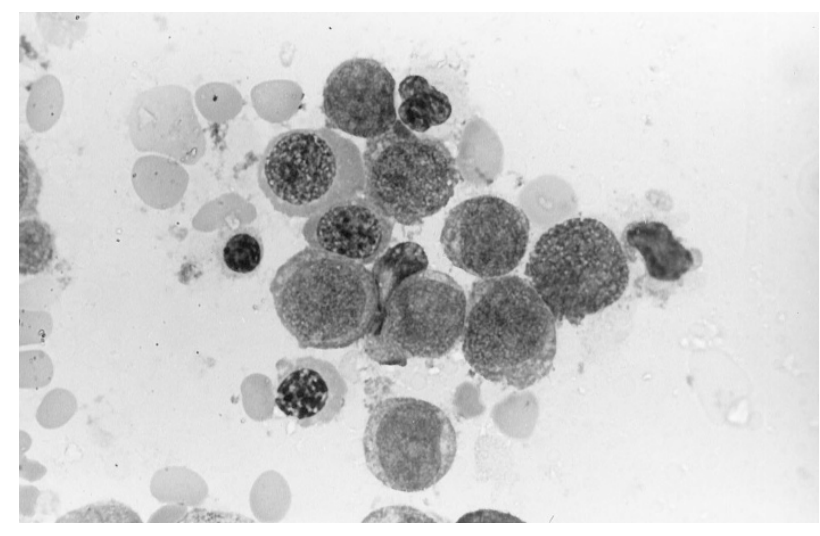

FIGURE 3. Representative photomicrograph of acute erythroleukemia, M6c (Wright-Giemsa stained aspirate smear, $1000 \times$ oil immersion). ings in the M6c subtype revealed 4 of 10 (40\%) with a strong stain and 6 with a weak immunostain (60\%) (Fig. 3). Positivity was predominantly within the less mature, blastic-appearing cells.

As a previous report demonstrated a negative additive effect of P-glycoprotein expression and unfavorable cytogenetic abnormalities (9), acute erythroleukemia patients with cytogenetic analyses and complete clinical data (survival, chemotherapy, and remission) were categorized according to P-glycoprotein expression and cytogenetic categories, as shown in Table 3 and Figure 4. Remission was achieved in all patients with negative and weakly positive immunohistochemical stain for P-glycoprotein. However, cases with a strongly positive stain demonstrated a decrease in the remission rate, depending on cytogenetic analysis: intermediate cytogenetics, one of two cases; unfavorable cytogenetics, zero of five cases. Statistical analyses on survival were performed for intermediate cytogenetics/negative P-glycoprotein stain and intermediate cytogenetics/weak P-glycoprotein stain $(P=.02)$, as well as intermediate cytogenetics/ negative P-glycoprotein stain and unfavorable cytogenetics/strongly positive stain $(P=.002)$.

\section{DISCUSSION}

Acute erythroleukemia is a relatively rare disorder of a multilineal nature. By traditional FAB criteria, the myeloblasts were believed to be the malignant component. However, recent studies (4-6) have proved that the pronormoblasts play a key role in the poor response to chemotherapy and short survival characteristic of this disorder. The dismal outlook for these patients, particularly the M6b and M6c subtypes, may also be partially explained by frequent p53 mutations within diagnostic bone marrow at initial diagnosis (12).

Besides its role in unregulated proliferation and clonal expansion, mutated p53 has been shown specifically to stimulate the $M D R-1$ promoter, whereas wild-type $p 53$ represses it $(13,14)$. P53 mutation does not lead to generalized drug resistance but rather causes selective resistance to P-glycoprotein substrates and increases sensitivity of the tumor cells to other drugs, such as methotrexate (13). An extensive study demonstrating this decreased growth inhibition by chemotherapeutic

TABLE 3. Remission Rate and Mean Survival Differences of Treated Patients Based on P-Glycoprotein Expression and Cytogenetics

\begin{tabular}{|c|c|c|c|c|}
\hline \multirow{2}{*}{ P-Glycoprotein } & \multicolumn{2}{|c|}{ Intermediate } & \multicolumn{2}{|c|}{ Unfavorable } \\
\hline & Remission & Mean Survival (mo) & Remission & Mean Survival (mo) \\
\hline Negative & $3 / 3$ & $83.7 \pm 43.8$ & $1 / 1$ & 19 \\
\hline Weakly positive & $4 / 4$ & $26.3 \pm 11.4$ & $3 / 3$ & $14.2 \pm 10$ \\
\hline Strongly positive & $1 / 2$ & $12.5 \pm 13.4$ & $0 / 5$ & $1.9 \pm 1.14$ \\
\hline
\end{tabular}




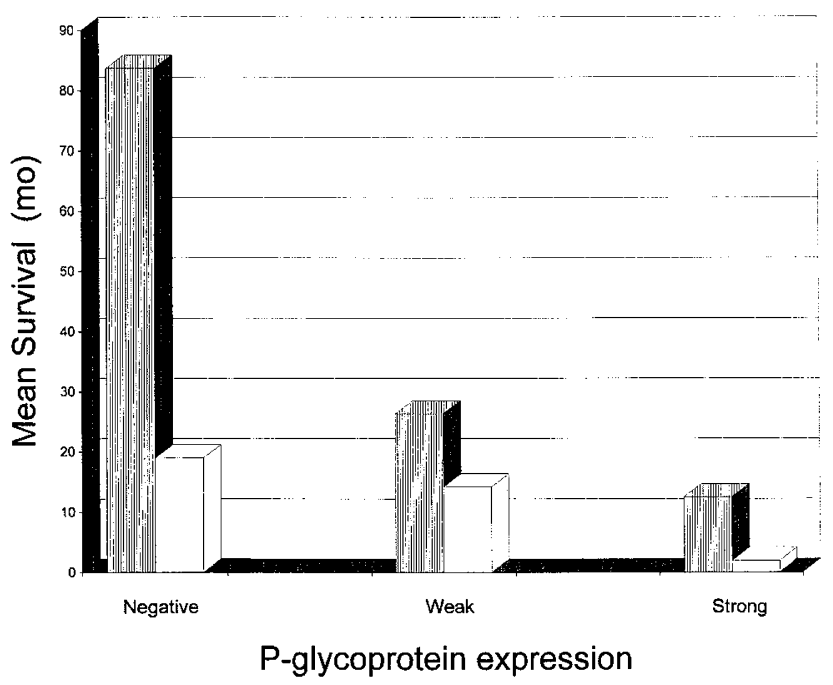

FIGURE 4. Schematic diagram of mean survival, based on Pglycoprotein expression and cytogenetics. Light grey, intermediate cytogenetics; dark grey, unfavorable cytogenetics.

agents (drug resistance) in the presence of p53 mutations was recently reported (15).

$\mathrm{P}$-glycoprotein is a transmembrane protein that functions as an energy-dependent drug efflux pump for selective resistance to anthracyclines (daunorubicin and doxorubicin), vinca alkaloids, podophyllotoxins (etoposide), antimicrotubule agents (paclitaxel and colchicine), and actinomycin $\mathrm{D}(1,13,16,17)$. This multidrug resistance may be reversed or overcome by such agents as calciumchannel blockers, analogs of anthracyclines and vinca alkaloids, steroids and hormonal analogs, cyclosporine analogs, and miscellaneous hydrophobic cationic compounds $(3,18-20)$. MDR-1 gene expression in acute leukemias has been documented extensively $(15,16,21-23)$ and is rapidly assuming the role of one of the most important mechanisms of drug resistance in this setting (9). These patients typically are resistant to standard myeloid protocol and thus have a poor prognosis (24). Occasionally, patients are able to achieve remission, but the remission is of short duration (25). Therefore, determining this phenotype is imperative for the institution of appropriate therapy. Review of the patient data in the present study reveals survival differences among the P-glycoprotein strongly positive, weakly positive, and negative patients. Of note, one of the P-glycoprotein weakly positive patients received erythropoietin (Patient $26)$, as there is a belief that this agent will cause erythroid maturation. A recent report (26), however, has shown that instead of inducing maturation, erythropoietin actually promotes erythroid progenitor survival, thereby promoting growth of the leukemic clone.

Although many of the M6a cases were P-glycoprotein negative (52.3\%), the patients with
M6b and M6c uniformly demonstrated positivity for P-glycoprotein. The majority of patients (86.7\%) with the M6b subtype demonstrated a strongly positive immunohistochemical staining pattern, lack of response to aggressive chemotherapy, and a dismal outcome. Patients with the M6c subtype and a strong reaction to P-glycoprotein fared slightly but not significantly better. The two patients with M6b and a weak P-glycoprotein were the only two patients of this subtype to achieve a brief remission and showed an improved survival (Patients 9 and 15). Similarly, the patients with M6c and a weak immunostain reaction also showed a slight survival advantage.

Most important, as previously demonstrated with other acute myelogenous leukemias (9), P-glycoprotein expression exhibits a statistically significant negative additive effect on response to chemotherapy (remission rate) and survival with unfavorable cytogenetic anomalies. These findings clearly demonstrate the clinical importance of assessment of both the MDR-1 expression and karyotype at the time of diagnosis in this patient population.

In summary, acute erythroleukemia is a stem cell disorder that has demonstrated a high incidence of immunohistochemical positivity for the protein product of $M D R-1$ at the time of diagnosis. This protein expression demonstrates a negative additive effect with cytogenetic aberrations and most probably contributes to the dismal prognosis in this patient population. Therefore, new chemotherapeutic regimens should be devised on the basis of the specific drug sensitivities of the leukemic cells, combined with $p 53$ gene status and the morphologic subtype of erythroleukemia.

\section{REFERENCES}

1. Bradley G, Juranka PF, Ling V. Mechanism of multidrug resistance. Biochim Biophys Acta 1988;948:87-128.

2. Shustik C, Dalton W, Gros P. P-glycoprotein-mediated multidrug resistance in tumor cells: biochemistry, clinical relevance and modulation. Mol Aspects Med 1995;16:1-78.

3. Sikic BI. Pharmacologic approaches to reversing multidrug resistance. Semin Hematol 1997;34:4(Suppl 5):40-7.

4. Kowal-Vern A, Cotelingam J, Schumacher HR. The prognostic significance of proerythroblasts in acute erythroleukemia. Am J Clin Pathol 1992;98:34-40.

5. Cuneo A, Van Orshoven A, Michaux JL, Boogaerts M, Louwagie A, Doyen C, et al. Morphologic, immunologic and cytogenetic studies in erythroleukemia: evidence for multilineage involvement and identification of two distinct cytogenetic-clinicopathological types. Br J Haematol 1990; 75:346-54.

6. Mazzella FM, Kowal-Vern A, Shrit MA, Wibowo AL, Rector JT, Cotelingam JD, et al. Acute erythroleukemia: evaluation of forty-eight cases with reference to classification, cell proliferation, cytogenetics and prognosis. Am J Clin Pathol 1998; 110:590-8.

7. Levine EG, Bloomfield CD. Leukemias and myelodysplastic 
syndromes secondary to drug, radiation, and environmental exposure. Semin Oncol 1992;19:47-84.

8. Arky R. Physicians' desk reference, 48th ed. Montvale, NJ: Medical Economics Data; 1994. pp. 673, 688, 825, 1539, 2072-73.

9. Willman C. The prognostic significance of the expression and function of multidrug resistance transporter proteins in acute myeloid leukemia: studies of the Southwest Oncology Group leukemia research program. Semin Hematol 1997;34: 4(Suppl 5):25-33.

10. Hsu SM, Cossman J, Jaffe ES. A comparison of ABC, unlabelled antibody, and conjugated immunohistochemical methods with monoclonal and polyclonal antibodies: an examination of germinal center tonsils. Am J Clin Pathol 1983;80:429.

11. Kawai K, Serizawa A, Hamana T, Tsutsumi Y. Heat-induced antigen retrieval of proliferating cell nuclear antigen and p53 protein in formalin-fixed, paraffin-embedded sections. Pathol Int 1994;44:759-64.

12. Mazzella FM, Tolbert D, Kowal-Vern A, Shrit MA, Rector JT, Cotelingam JD, et al. P53 gene mutation in acute erythroleukemia: differences among subtypes M6a, M6b and M6c. Lab Hematol 1999;5:28-36.

13. Thottassery JV, Zambetti GP, Armori K, Schuetz EG, Schuetz JD. P53-dependent regulation of MDR1 gene expression causes selective resistance to chemotherapeutic agents. Proc Natl Acad Sci U S A 1997;94:11037-42.

14. Chin KV, Ueda K, Pastan I, Gottesman MM. Modulation of activity of the promoter of the human MDR1 gene by ras and p53. Science 1992;255:459-62.

15. O'Connor PM, Jackman J, Bae I, Myers TG, Fan S, Mutoh M, et al. Characterization of the p53 tumor suppressor pathway in cell lines of the National Cancer Institute anticancer drug screen and correlations with the growth-inhibitory potency of 123 anticancer agents. Cancer Res 1997;57:4285-300.

16. Pirker R, Wallner J, Geissler K, Linkesch W, Haas OA, Bettelheim $\mathrm{P}$, et al. MDR1 gene expression and treatment outcome in acute myeloid leukemia. J Natl Cancer Inst 1991;83:708-12.

17. Carulli G, Petrini M, Marini A, Vaglini F, Caracciolo F, Grassi B. P-glycoprotein and drug resistance in acute leukemias and in the blastic crisis of chronic myeloid leukemia. Haematologica 1990;75:516-21.

18. Pasman PC, Schouten HC. Multidrug resistance mediated by p-glycoprotein in hematological malignancies. Neth J Med 1993;42:218-31.

19. Pastan I, Gottesman M. Multiple-drug resistance in human cancer. N Engl J Med 1987;316:1388-93.

20. Advani R, Saba HI, Tallman MS, Rowe JM, Wiernik PH, Ramek J, et al. Treatment of refractory and relapsed acute myelogenous leukemia with combination chemotherapy plus the multidrug resistance modulator PSC 833 (Valspodar). Blood 1999;93:787-95.

21. Marie JP, Zittoun R, Sikic BI. Multidrug resistance (MDR1) gene expression in adult acute leukemias: correlations with treatment outcome and in vitro drug sensitivity. Blood 1991; 78:586-92.

22. Sato H, Preisler H, Day R, Raza A, Larson R, Browman G, et al. MDR1 transcript levels as an indication of resistant disease in acute myelogenous leukemia. Br J Haematol 1990; 75:340-5.

23. Dalton WS. Mechanisms of drug resistance in hematologic malignancies. Semin Hematol 1997;34:4(Suppl 5):3-8.

24. Preisler HD, Raza A, Barcos M, Azarnia N, Larson R, Walker I, et al. High dose cytosine arabinoside as the initial treatment of poor risk patients with acute non-lymphocytic leukemia: a Leukemia Intergroup Study. J Clin Oncol 1987;5:7582.

25. Preisler HD, Raza A. Chemotherapeutic strategies in the treatment of patients with acute non-lymphocytic leukemia in complete remission. Hem Rev 1987;2:13-43.

26. Silva M, Grillot D, Benito A, Richard C, Nunez G, FernandezLuna JL. Erythropoietin can promote erythroid progenitor survival by repressing apoptosis through Bcl-XL and Bcl-2. Blood 1996;88:1576-82. 